\title{
COUPLING OF ECONOMIC BENEFITS AND CLIMATE CHANGE ADAPTATION: REFLECTION FROM A SMALL MUNICIPALITY DEVELOPMENT PLAN
}

\author{
MOHAMMAD BARAD HOSSAIN CHOWDHURY* \\ School of Design and the Built Environment, Curtin University, Australia
}

\begin{abstract}
Recent global climate data clearly indicates adaptation to climate change could be one of the preeminent ways to deal with future climate uncertainties. The paradigm shift from mitigation to adaptation clearly focused on local context. Local governments (LGs), especially in the cities, are viewing this as a significant platform to include adaptation options in their development agenda. In such milieu, this study aims to find how the agents responsible for planning of a small municipality see climate change adaptation along with infrastructure development, service delivery and economic benefit. This study qualitatively analyses the planning documents for the investigation. The result confirms that, when local economic benefits are on top of the municipality's development agenda, climate adaptation provisions become secondary. Combined with the lack of national adaptation policies, unclear climate datasets and local political incongruity, the adaptation initiatives at the small municipality level remain nebulous. Such development planning with a blurry adaptation needs to put adequate attention to climate knowledge and adaptation provisions.
\end{abstract}

Keywords: adaptation, municipality, planning, master plan, plan quality, city, climate change.

\section{INTRODUCTION}

Climate change (CC), as described by scholars, is an ultimate "wicked problem" with a large spatial and temporal scale beyond individual nation's ability to take action [1]. Therefore, an urgent call has been made for global initiatives to see it as "not a problem to solve" but collectively act on it as it is a "condition in which we are enmeshed" [1, p. 363]. Recent global climate data clearly indicates that, adaptation to climate change is one of the preeminent ways to deal with such wicked problems because some impacts of climate change are irreversible [2]. The $1.5^{\circ} \mathrm{C}$ Report of Intergovernmental Panel on Climate Change (IPCC) sees climate change adaptation (CCA) as an increasingly urgent need to address [3]. Taking adaptation actions and its proper documentation has entered as a nationwide mandated priority [2]. A notable feature of calls for a paradigm shift from mitigation to adaptation clearly focused on local context and local governments (LGs) are seeing the most significant impact of climate adaptation [4]-[8]. LGs, especially in urban settings, are again struggling to prioritize the adaptation while they find themselves entangled in the complex issues of local politics, development, community mandates and better services [7]. Therefore, adaptation is one of the many agenda in local development perspectives [4]. On the other hand, in spite of having a plethora of scientific researches on urban climate and urban planning, there is still a significant gap between climatologists and planners [9]. Urban planning extensively needs to incorporate atmospheric information to address future climatic events, otherwise future climatic events will be more challenging [10]. Urban landscapes generally differ from the rural landscapes in respect to climate change impact [9]. Planning of a city therefore requires adequate attention of climate knowledge and adaptation provisions. Research shows that little attention has been paid to climate issues while planning

* ORCID: https://orcid.org/0000-0001-8015-4533 
for a municipal city or a secondary city [9], [11]. Very limited impact of climate knowledge has been evidenced with such planning despite these cities (municipalities) being institutionally responsible to shape their landscape development through masterplan, land use and infrastructure policies [12]. The municipal masterplan is an impermanent constitution [13] that helps municipalities to shape their development and service delivery [12]. It has evolved in transition of conventional suburban development to an urban-rural form in $20^{\text {th }}$ century with initial aim to create substantial influence in the development and uses of local landscape within local perspectives [12]. The masterplan has been used as a tool of decision making process in local development where management of planning and development is non-linear and often messy [14], [15]. It also helps to shape a local landscape, combine local economy with land use planning and carefully consider environmental change [16], [17]. It is often termed as a communicative policy act because it provides local vision (how local people want to see the development), informs corresponding policies and adopts management programs to achieve local vision [12]. But in this climate era masterplans are subject to examination through the lens of CCA to justify the CCA inclusiveness and climate preparedness in future planning. Here is lays the gap. Incorporation of climate projection in municipality masterplan is still rare except for megacities or smart cities. Research on this gap is scanty. Plan quality research rarely uses CCA attributes as a quality measurement criteria. Some studies tried to incorporate environment assessment in planning [18] but not CCA. Therefore this study aims to analyse the current masterplan of a small municipality of Bangladesh named Satkhira municipality to understand to what extent the future climatic projections had been reflected in its development plan. Satkhira as a coastal district headquarters carries a number of geo-positional as well as regional economic and ecological importance. The Satkhira municipality masterplan (SMMP) prepared to identify and implement physical development to enhance overall economic growth, ensure better lives and livelihoods as well as to improve the capacity of the municipality towards better service delivery. But how it couples the development and climate adaptation in the future plans is the area of research interest. Therefore, this study aims to answer the following question: "how the planning of a municipality embrace climate change adaptation in their planning along with infrastructure development and economic benefit?"

\section{BACKGROUND:}

Satkhira Municipality (local term Paurashava) is a small district town (declared as a town in 1869) spatially positioned in between $21^{\circ} 36^{\prime}$ and $21^{\circ} 54^{\prime}$ North latitudes and between $88^{\circ} 54^{\prime}$ and $89^{\circ} 20^{\prime}$ East longitudes in southern-western of Bangladesh (Fig. 1) with an area of $33.66 \mathrm{sq}$. $\mathrm{km}$ and divided into 9 wards (smallest unit of local government). It is an isolated small town at the south-west corner of Bangladesh with a significant economic contribution towards the national economy through fisheries business (especially shrimp) and land port operation between India and Bangladesh. It is only $75 \mathrm{~km}$ away from the world's largest mangrove forest named Sundarbans. This commercially and ecologically important administrative headquarter of Satkhira district is exposed to the risk of significant climate variability due to its geographical location [19], [20]. Past climate data significantly demonstrates the existing vulnerabilities and gives a clear views of future uncertainties. Including the threat of tropical cyclone, floods and salinity intrusion, it is in major risk of inundation in the course of monsoon because it is located in between two polders. In case of heavier monsoon rain the water level of those polders invades into the urban area and creates severe waterlogging problems. Climate change triggered rainfall is expected to increase by $25 \%$ over the next 30 years which definitely indicates a more severe waterlogging 

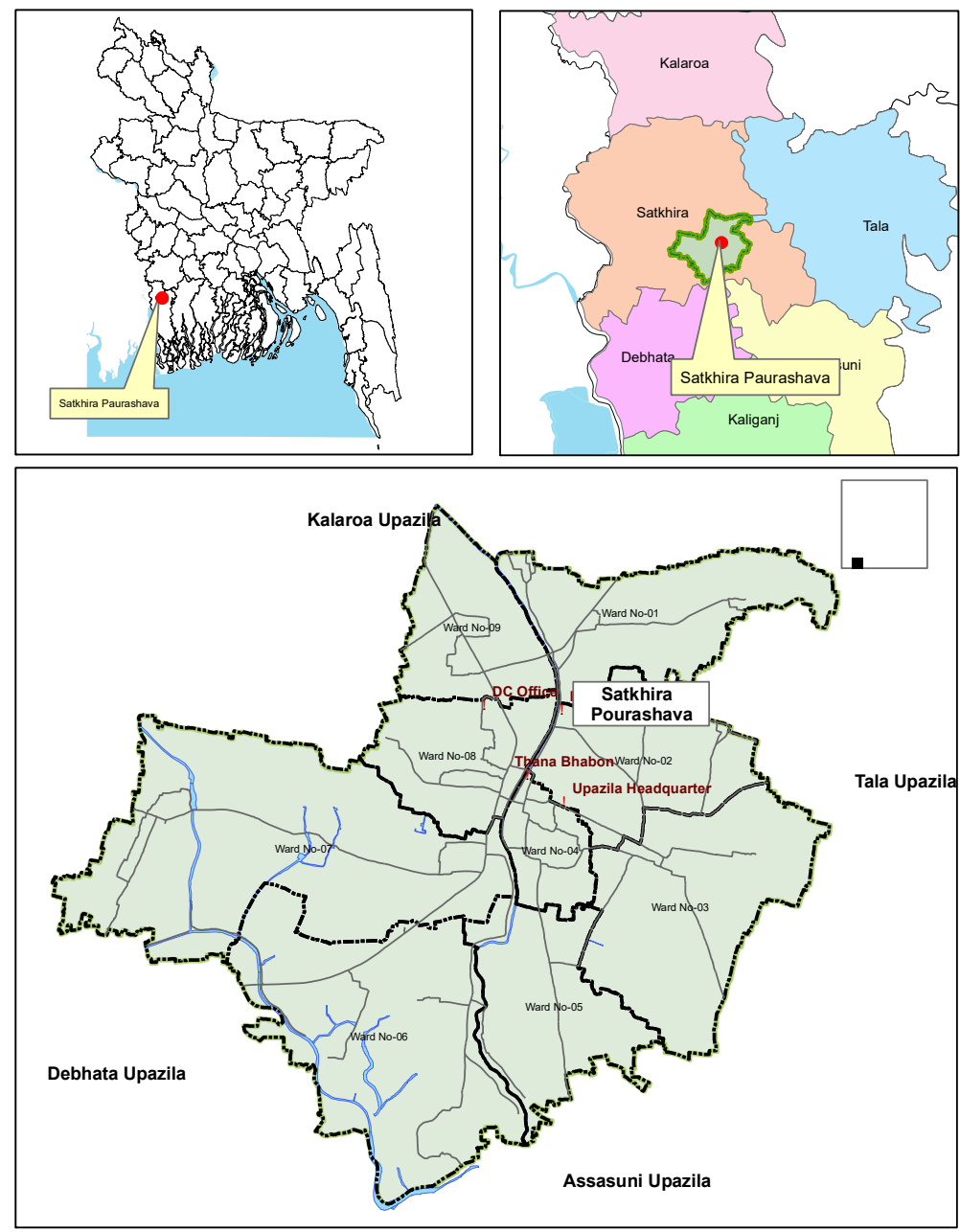

Figure 1: Location map of Satkhira Municipality (Paurasava) adopted from SMMP.

in future. Developing plans for dealing with such highly disruptive climate events, which is expected more frequently in future, is a priority for the municipality. A strong coordination between municipality planners, disaster management authorities and climatologists is a prime requirement.

Historically, planning practices at municipality or small town level is not yet mainstreamed in Bangladesh. Urban Development Directorate under the Ministry of Local Government, Rural Development and Cooperatives (MoLGRDC) initiated a number of master plans for municipalities in the 1980s which has never been gazetted for implementation. Moreover, there were no town planners in municipalities until 2006. In 2008 the Local Government Engineering Department (LGED) initiated to prepare masterplans for 235 municipalities under two urban development projects. The SMMP is one of them which has been completed in early 2014. It aims to provide necessary infrastructure development with provision to expand the area of the municipality (the green coloured zone in Fig. 2). 


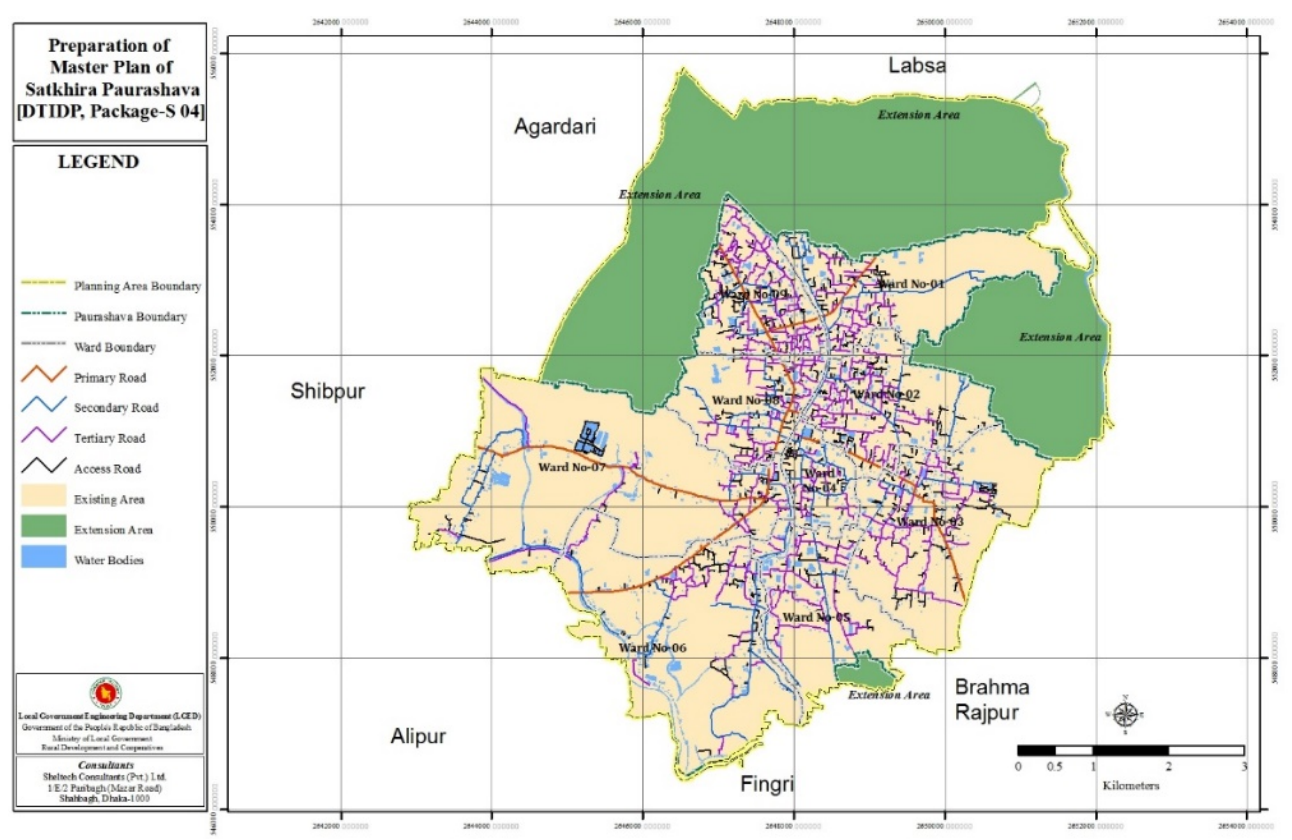

Figure 2: Planning area of Satkhira Municipality under SMMP adopted from SMMP.

\section{THE SMMP}

The SMMP consists of three components, such as, Structure Plan (SP), Urban Area Plan (UAP) and Ward Action Plan (WAP). The structure plan is seen as a guiding component for the other two planning components.

\subsection{Structure Plan (SP)}

It is intended to cover the development strategies for a period of 20 years (2011-2031) for land use and urban growth expressed in terms of policy integration with national and regional development policies. It has discussed the population projection and proposed broad land use categories to embrace growth. In-depth examination of related polices has been discussed with possible strength and weakness.

\subsection{Urban Area Plan (UAP)}

It has articulated the spatial development strategies on a medium-term basis (10 years). It captured the broad development guidelines stated by the SP. It has four major components which are the core of the development of the municipality: Land use plan (15 categories of land use zoning identified); Transportation and traffic management plan (plan to develop transportation corridor aligned with local and regional needs); Drainage and Environmental Management Plan (plan to develop drainage network hierarchy and protect the environment quality with efficient disposal of solid waste); and Plan for Urban Services (plan to seamlessly supply of urban utilities such as electricity, water, gas as well as maintain uninterrupted sewerage system). 


\subsection{Ward Action Plan (WAP)}

This short term (5 years) development plan consists of a number of ward level priority schemes. Schemes were prioritised based on the existing development patterns and the needs for future development. Considering population, distance from the city centre and suitability of land, most of the urban social services were proposed to be made available to citizens within a range of 1 to $2 \mathrm{~km}$.

\section{METHODOLOGY}

Research on plan quality as a useful tool to measure the attributes of a plan (for example, strength and deficiencies) has been proliferated since early 1990s [21]. Remarkable expansion has been evidenced in the plan quality framework starting from core attributes (base fact, goals or policies) to recent management tools (monitoring and evaluation, public participation) in order to bring the accuracy of the plan quality assessment [22], [23] as well as present it as a communicative tool to engage readers [24], [25]. Researchers are using a number of contented and communicative characteristics of the plan, combined or separately to assess the overall quality of a plan [21], [25]. Conventionally, plan quality research assesses the plan contents, policy focus, analytical quality and plan consistency [12]. In some specific plans, such as CCA plans, plans consist of more recent management attributes such as participation, monitoring and evaluation or inter-organizational coordination are also analysed [21], [25]. This research, based on such a conceptual framework, uses five clusters of plan attributes to justify the coupling of CCA and economic development in SMMP, such as fact base, goals and objectives, environmental quality, policies and climate change adaptation. As it is the lens of CCA each cluster of attributes has been judged by the presence or absence of certain observed indicators of CCA representing the respective cluster. A coding protocol has been developed to evaluate the quality of SMMP through the observed indicators (Table 1). Measurements are done by assigning a binary scale against each of the observed indicator such as score " 1 " is assigned if the indicator was present in the plan and assigned score " 0 " if the indicator is absent. Calculations are done as mean scores such as total observed score divided by total possible score which is in the scale of 0 to 1 .

For more clarity, this study only uses the attributes related to CCA, but not all the plan qualities. Therefore, it may create some over or under valuation of different characteristics which may not reflect overall plan quality or whole plan consistency. With this limitation this study seeks to obtain a new platform of plan quality research which can directly be judged by CCA attributes.

\section{RESULT AND DISCUSSION}

Quantitative results show the mean score of each plan attributes of SP, UAP and WAP varied significantly and clearly indicates the poor coupling of CCA in the SMMP. Fig. 3 summaries the evaluation of plan quality in regards of CCA with mean scores. Among the three components of SMMP, UAP is more CCA inclusive with sum of mean score 2.5 over the scale of 1 to 5 than SP and WAP with sum of mean score 2.21 and 1.43 respectively (Fig. 4).

The mean score for fact base attributes varies among the three components of SMMP with the score of 0.5, 0.6 and 0.3 for SP, UAP and WAP respectively. It indicates that the SMMP did not provide comprehensive information towards CCA. Regarding the goals and objectives of SMMP, the mean score indicates the total failure of having articulated CCA objectives (score ranges from 0 to 0.33 ). It clearly indicates that the main focus of SMMP was structural development and physical expansion to achieve economic benefits. However, 
Table 1: Description of CCA related plan attributes of SMMP.

\begin{tabular}{|c|c|c|c|c|}
\hline \multirow{2}{*}{ Cluster } & \multirow{2}{*}{ Attributes } & \multicolumn{3}{|c|}{ Score $(\mathrm{Yes}=1, \mathrm{No}=0)$} \\
\hline & & SP & UAP & WAP \\
\hline \multirow{12}{*}{$\begin{array}{l}\text { Fact base: It frames } \\
\text { the current } \\
\text { situation with trend } \\
\text { analysis of } \\
\text { demographic, } \\
\text { economic and } \\
\text { environmental } \\
\text { trends to justify the } \\
\text { future priorities of } \\
\text { the masterplan. }\end{array}$} & $\begin{array}{l}\text { Does the plan include possible causes of } \\
\text { CC? }\end{array}$ & 0 & 0 & 0 \\
\hline & $\begin{array}{l}\text { Does the plan describe local context of } \\
\text { CC? }\end{array}$ & 1 & 1 & 0 \\
\hline & $\begin{array}{l}\text { Does the plan describe global context of } \\
\text { CC? }\end{array}$ & 0 & 0 & 0 \\
\hline & $\begin{array}{l}\text { Does the plan consider present land and } \\
\text { water uses? }\end{array}$ & 1 & 1 & 1 \\
\hline & $\begin{array}{l}\text { Does the plan describe the local } \\
\text { contribution towards CC? }\end{array}$ & 0 & 0 & 0 \\
\hline & $\begin{array}{l}\text { Does the plan consider the general } \\
\text { impacts of CC? }\end{array}$ & 1 & 1 & 0 \\
\hline & $\begin{array}{l}\text { Does the plan mark the specific } \\
\text { jurisdiction of CC impact? }\end{array}$ & 0 & 1 & 0 \\
\hline & $\begin{array}{l}\text { Does the plan analyse the population } \\
\text { trends impacted by CCA? }\end{array}$ & 1 & 1 & 1 \\
\hline & $\begin{array}{l}\text { Does the plan analyse the previous } \\
\text { natural disasters? }\end{array}$ & 1 & 1 & 1 \\
\hline & $\begin{array}{l}\text { Does the plan analyse climate } \\
\text { displacement? }\end{array}$ & 0 & 0 & 0 \\
\hline & Total score & 5 & 6 & 3 \\
\hline & Mean score & 0.50 & 0.60 & 0.30 \\
\hline \multirow{8}{*}{$\begin{array}{l}\text { Goals and } \\
\text { objectives: These } \\
\text { ambition } \\
\text { statements describe } \\
\text { the desirability of } \\
\text { the masterplan. }\end{array}$} & Does the plan set broad goals for CCA? & 0 & 0 & 0 \\
\hline & $\begin{array}{l}\text { Does the plan identify any specific goals } \\
\text { for CCA? }\end{array}$ & 0 & 1 & 0 \\
\hline & $\begin{array}{l}\text { Does the plan set broad goals for } \\
\text { mitigation? }\end{array}$ & 0 & 0 & 0 \\
\hline & $\begin{array}{l}\text { Does the plan identify any specific goals } \\
\text { for mitigation? }\end{array}$ & 0 & 0 & 0 \\
\hline & $\begin{array}{l}\text { Does the plan set long-term target for } \\
\text { reducing CC impact? }\end{array}$ & 1 & 1 & 0 \\
\hline & $\begin{array}{l}\text { Does the plan set the target to reduce the } \\
\text { climate displacement? }\end{array}$ & 0 & 0 & 0 \\
\hline & Total score & 1 & 2 & 0 \\
\hline & Mean score & 0.16 & 0.33 & 0.00 \\
\hline \multirow{4}{*}{$\begin{array}{l}\text { Environmental } \\
\text { qualities: attributes } \\
\text { which describe } \\
\text { general } \\
\text { environmental } \\
\text { management } \\
\text { strategies. }\end{array}$} & $\begin{array}{l}\text { Does the plan include provisions to } \\
\text { maintain natural vegetation? }\end{array}$ & 1 & 1 & 0 \\
\hline & $\begin{array}{l}\text { Does the plan include provisions to } \\
\text { maintain vegetative buffer, especially } \\
\text { near sensitive natural areas? }\end{array}$ & 0 & 1 & 1 \\
\hline & $\begin{array}{l}\text { Does the plan set the buffer zone for } \\
\text { agricultural areas? }\end{array}$ & 1 & 1 & 1 \\
\hline & $\begin{array}{l}\text { Does the plan include water shed } \\
\text { management? }\end{array}$ & & & \\
\hline
\end{tabular}


Table 1: Continued.

\begin{tabular}{|c|c|c|c|c|}
\hline \multirow{2}{*}{ Cluster } & \multirow{2}{*}{ Attributes } & \multicolumn{3}{|c|}{ Score $(\mathrm{Yes}=1, \mathrm{No}=0)$} \\
\hline & & SP & SP & $\mathrm{SP}$ \\
\hline \multirow[t]{4}{*}{$\begin{array}{l}\text { Environmental } \\
\text { qualities continued. }\end{array}$} & $\begin{array}{l}\text { Does the plan set the provision of } \\
\text { pollutants (fertilizer/pesticides) control? }\end{array}$ & 0 & 0 & 0 \\
\hline & $\begin{array}{l}\text { Does the plan provide adequate provision } \\
\text { towards awareness/education on CC? }\end{array}$ & 1 & 0 & 0 \\
\hline & Total score & 3 & 3 & 2 \\
\hline & Mean score & 0.60 & 0.60 & 0.40 \\
\hline \multirow{11}{*}{$\begin{array}{l}\text { Policies: Policies } \\
\text { are discussed as a } \\
\text { guidance of the } \\
\text { masterplan to } \\
\text { promote } \\
\text { acceptance and } \\
\text { provide a legal } \\
\text { source of the plan. }\end{array}$} & $\begin{array}{l}\text { Does the plan include policies related to } \\
\text { CC? }\end{array}$ & 1 & 1 & 0 \\
\hline & Does the plan include energy policy? & 0 & 0 & 0 \\
\hline & $\begin{array}{l}\text { Does the plan include Coastal Zone } \\
\text { development policy? }\end{array}$ & 1 & 1 & 1 \\
\hline & Does the plan include Land Use policy? & 1 & 1 & 1 \\
\hline & $\begin{array}{l}\text { Does the plan include Renewable Energy } \\
\text { policy? }\end{array}$ & 0 & 0 & 0 \\
\hline & Does the plan include Industrial policy? & 0 & 1 & 0 \\
\hline & Does the plan include Tourism policy? & 1 & 0 & 0 \\
\hline & Does the plan include Agriculture policy? & 1 & 0 & 1 \\
\hline & $\begin{array}{l}\text { Does the plan include any Water } \\
\text { Reservoir Conservation policy? }\end{array}$ & 1 & 1 & 1 \\
\hline & Total score & 6 & 5 & 4 \\
\hline & Mean score & 0.66 & 0.55 & 0.44 \\
\hline \multirow{9}{*}{$\begin{array}{l}\text { CCA: It represent } \\
\text { the incorporation } \\
\text { of activities which } \\
\text { directly or } \\
\text { indirectly related } \\
\text { with adaptation } \\
\text { towards future } \\
\text { climate } \\
\text { uncertainties. }\end{array}$} & $\begin{array}{l}\text { Does the plan include at least one CCA } \\
\text { policy (NAPA, BCCSAP) to incorporate } \\
\text { CCA provision? }\end{array}$ & 0 & 0 & 0 \\
\hline & $\begin{array}{l}\text { Does the plan identify possible potential } \\
\text { of community based adaptation (CBA)? }\end{array}$ & 0 & 1 & 0 \\
\hline & $\begin{array}{l}\text { Does the plan include renewable energy } \\
\text { as a means of CCA? }\end{array}$ & 0 & 0 & 0 \\
\hline & $\begin{array}{l}\text { Does the plan include any retrofits of } \\
\text { existing infrastructure towards CCA? }\end{array}$ & 1 & 1 & 0 \\
\hline & $\begin{array}{l}\text { Does the plan include any infrastructure } \\
\text { as a priority of CCA? }\end{array}$ & 0 & 0 & 1 \\
\hline & $\begin{array}{l}\text { Does the plan include any provisions of } \\
\text { enhance the adaptive capacity of the } \\
\text { municipality? }\end{array}$ & 1 & 1 & 1 \\
\hline & $\begin{array}{l}\text { Does the plan include any specific } \\
\text { measures towards adaptive capacity of } \\
\text { the citizen? }\end{array}$ & 0 & 0 & 0 \\
\hline & Total score & 2 & 3 & 2 \\
\hline & Mean score & 0.29 & 0.42 & 0.29 \\
\hline
\end{tabular}


438 Sustainable Development and Planning XI

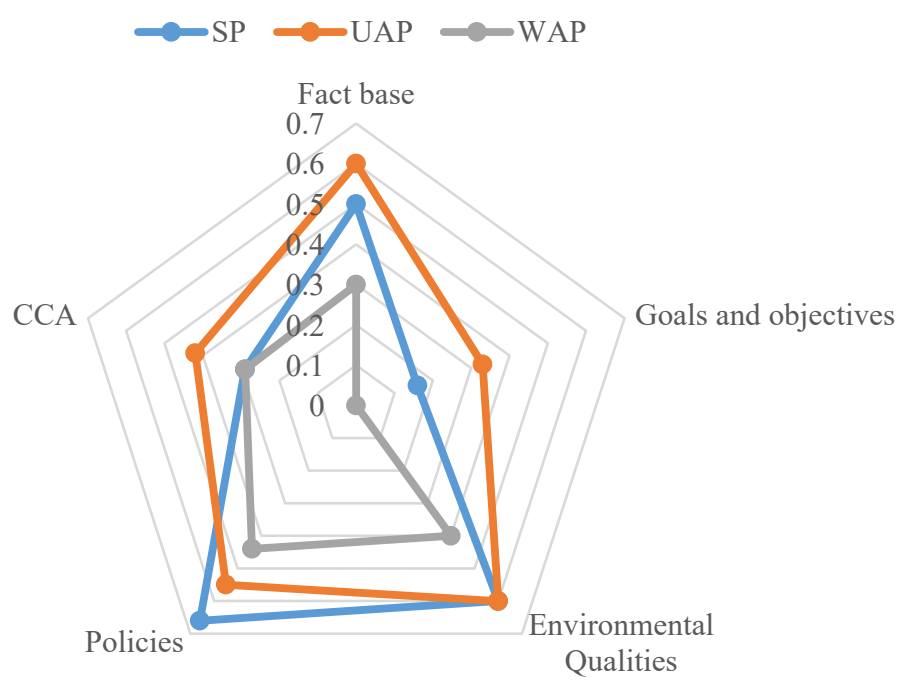

Figure 3: Mean scores of plan quality attributes towards CCA inclusion.

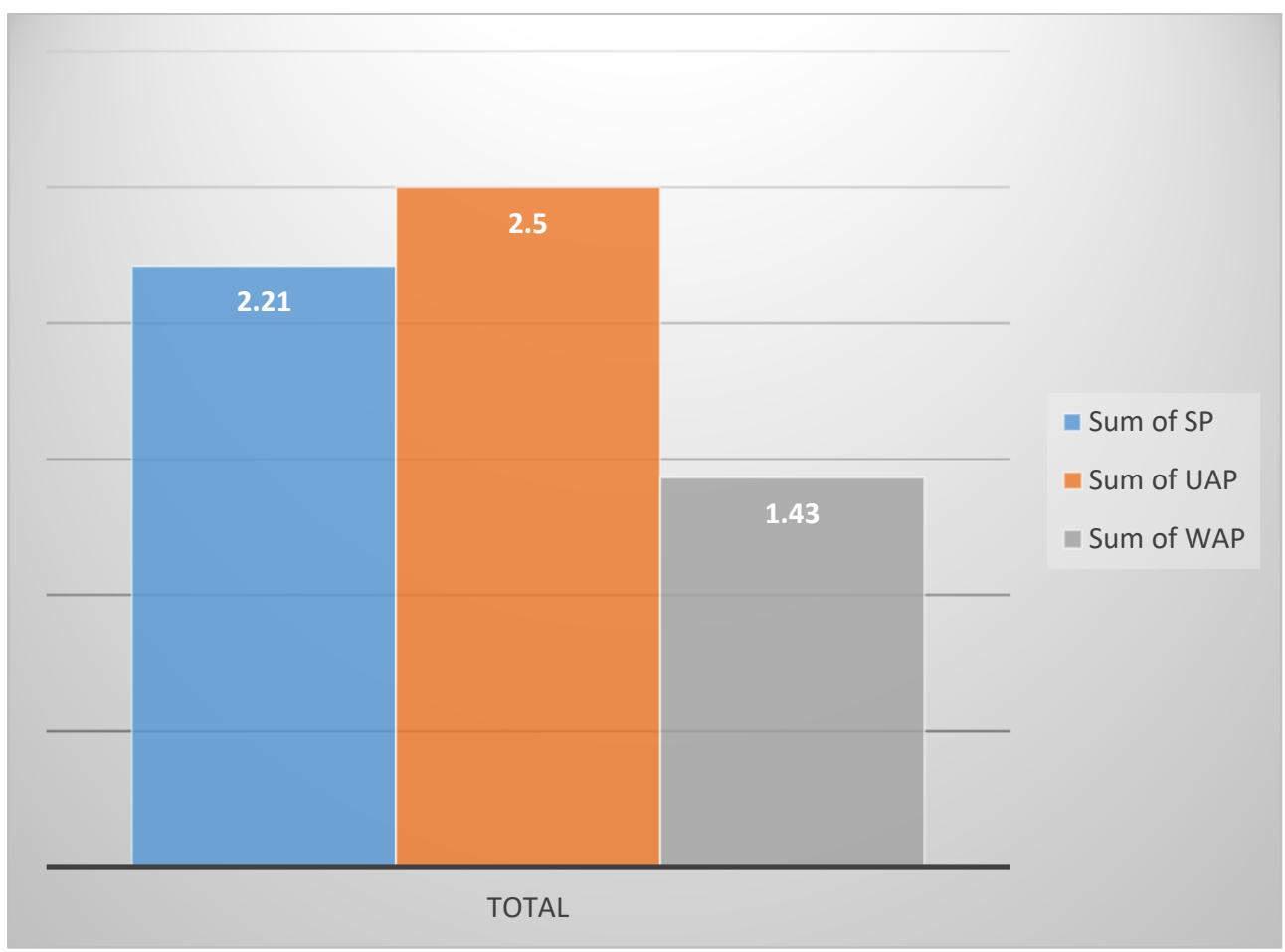

Figure 4: Sum of total mean scores of the components of SMMP. 
the SMMP tried to inform the attributes which provides general environmental management strategies in a relatively fair way. The mean score for both SP and UAP 0.6 indicates a substantial effort has been made to inform the existing environmental management practices. It also fairly articulated the policies directly or indirectly related to CCA with mean score of $0.66,0.55$ and 0.44 for SP, UAP and WAP respectively. However, they failed to incorporate some very significant CCA policies such as Renewable Energy Policy, 2008. Therefore, it looks very under represented by the inclusion of CCA when SMMP were examined through the lens of CCA. The lowest mean scores for CCA, 0.29 for both SP and WAP and 0.42 for UAP, represent a substantial failure to articulate the rationale of CCA inclusion in SMMP.

Urban planning, especially for coastal cities, needs to consider the vulnerability of both long term and short term variability of CC, specially the SLR, storm surge and salinity intrusion [4], [26], [27]. Therefore, regional climate change predictions should be included in the plan with the meteorological information and information of impact of $\mathrm{CC}$ at the appropriate scale [9]. This requires the wholescale knowledge of cities responding capacities, human influences and future climate variability projections. Despite the initial aims of masterplans, now in this climate era the masterplans are subject to examination through the lens of climate change adaptation and preparedness. But when the local development priorities are on top of the LG's agenda, adaptation provisions become secondary [7]. Combined with the lack of or weak national adaptation policies and unclear climate datasets, the adaptation initiatives at local level remain unclear. This study clearly evidence such development initiatives with a blurred adaptation indication in SMMP. And it is not surprising that for a secondary city in Bangladesh. Satkhira municipality, as the headquarter of one of the most climate vulnerable and poor coastal district of Bangladesh, is suffering from poor infrastructures, transport, drainage, sanitation and water supply system, and is in need of better physical development to support urban growth. Hence, the SMMP clearly aimed to identify the main development issues and implement programs accordingly. This study clearly supports evidence that the SMMP is more inclined to physical development and expansion to gain economic growth than CCA focused development initiatives.

\section{CONCLUSION}

Bangladesh is one of the world's most climate vulnerable countries with existing chronic poverty. City planning are still at its infancy, especially for secondary cities. A strong planning department at city level is a crying need amid huge demands for future climate sensitive planning. This study is the first attempt to examine city planning through CCA lens which finds a significant blurred or grey area between developmental needs and CCA integration. Coupling of both development issues and CCA initiatives can bring the win-win solution in city planning to harness the best possible improvement to economic and ecological indicators. Future research can unwind the complexities lays underneath this coupling mechanism.

\section{REFERENCES}

[1] Hulme, M., Why We Disagree About Climate Change: Understanding Controversy, Inaction and Opportunity, Cambridge University Press, 2009.

[2] Magnan, A.K. \& Ribera, T., Global adaptation after Paris. Science, 352(6291), pp. 1280-1282, 2016.

[3] Berrang-Ford, L. et al., Tracking global climate change adaptation among governments. Nature Climate Change, 9(6), pp. 440-449, 2019. 
[4] Nalau, J., Preston, B.L. \& Maloney, M.C., Is adaptation a local responsibility? Environmental Science \& Policy, 48, pp. 89-98, 2015.

DOI: $10.1016 /$ j.envsci.2014.12.011.

[5] Deri, A., Local governments and climate change, 2008.

[6] Mees, H., Local governments in the driving seat? A comparative analysis of public and private responsibilities for adaptation to climate change in European and NorthAmerican cities. Journal of Environmental Policy and Planning, 19(4), pp. 374-390, 2017. DOI: 10.1080/1523908X.2016.1223540.

[7] Mukheibir, P., Kuruppu, N., Gero, A. \& Herriman, J., Overcoming cross-scale challenges to climate change adaptation for local government: a focus on Australia. Climatic Change, 121(2), pp. 271-283, 2013. DOI: 10.1007/s10584-013-0880-7.

[8] Fallon, D.S.M. \& Sullivan, C.A., Are we there yet? NSW local governments' progress on climate change. Australian Geographer, 45(2), pp. 221-238, 2014.

DOI: $10.1080 / 00049182.2014 .899030$.

[9] Eliasson, I., The use of climate knowledge in urban planning. Landscape and Urban Planning, 48(1-2), pp. 31-44, 2000.

[10] Grimmond, C. et al., Climate and more sustainable cities: Climate information for improved planning and management of cities (producers/capabilities perspective). Procedia Environmental Sciences, 1, pp. 247-274, 2010.

[11] Reckien, D. et al., How are cities planning to respond to climate change? Assessment of local climate plans from 885 cities in the EU-28. Journal of Cleaner Production, 191, pp. 207-219, 2018.

[12] Norton, R.K., Using content analysis to evaluate local master plans and zoning codes. Land Use Policy, 25(3), pp. 432-454, 2008.

[13] Haar, C.M., The master plan: An impermanent constitution. Law and Contemporary Problems, 20(3), pp. 353-418, 1955.

[14] Qian, Z., Master plan, plan adjustment and urban development reality under China's market transition: A case study of Nanjing. Cities, 30, pp. 77-88, 2013.

[15] Nelson, L.M., The master plan and Subdivision Control. Maine Law Review, 16, pp. 107, 1964.

[16] Baynham, M. \& Stevens, M., Are we planning effectively for climate change? An evaluation of official community plans in British Columbia. Journal of Environmental Planning and Management, 57(4), pp. 557-587, 2014.

[17] Bassett, E. \& Shandas, V., Innovation and climate action planning: Perspectives from municipal plans. Journal of the American Planning Association, 76(4), pp. 435-450, 2010.

[18] Alshuwaikhat, H.M. \& Aina, Y.A., Sustainable planning: The need for strategic environmental assessment-based municipal planning in Saudi Arabia. Journal of Environmental Assessment Policy and Management, 7(3), pp. 387-405, 2005.

[19] Rimi, R.H., Rahman, S.H. \& Abedin, M., Recent climate change trend analysis and future prediction at Satkhira District, Bangladesh. IOP Conference Series: Earth and Environmental Science, 6(47), pp. 1755-1307, 2009.

[20] Hasan, M.A. et al., A Comparative Analysis of cmip3 and cmip5 Climate Projections over Bangladesh. 5th International Conference on Water and Flood Management, Dhaka, pp. 6-8, 2015.

[21] Lyles, W. \& Stevens, M., Plan quality evaluation 1994-2012: Growth and contributions, limitations, and new directions. Journal of Planning Education and Research, 34(4), pp. 433-450, 2014. 
[22] Berke, P. \& Godschalk, D., Searching for the good plan: A meta-analysis of plan quality studies. Journal of Planning Literature, 23(3), pp. 227-240, 2009.

[23] Godschalk, D., Beatley, T., Berke, P., Brower, D. \& Kaiser, E.J., Natural Hazard Mitigation: Recasting Disaster Policy and Planning, Island Press, 1998.

[24] Bunnell, G. \& Jepson Jr, E.J., The effect of mandated planning on plan quality: A fresh look at what makes "a good plan". Journal of the American Planning Association, 77(4), pp. 338-353, 2011.

[25] Guyadeen, D., Thistlethwaite, J. \& Henstra, D., Evaluating the quality of municipal climate change plans in Canada. Climatic Change, 152(1), pp. 121-143, 2019.

[26] Lundqvist, L.J., Planning for climate change adaptation in a multi-level context: The Gothenburg metropolitan area. European Planning Studies, 24(1), pp. 1-20, 2016.

[27] Stokke, K.B., Adaptation to sea level rise in spatial planning-Experiences from coastal towns in Norway. Ocean \& Coastal Management, 94, pp. 66-73, 2014. 